\title{
LAPORAN KASUS KEJADIAN LUAR BIASA LEPTOSPIROSIS DI MAGETAN, JAWA TIMUR
}

\author{
Rosa De Lima Renita Sanyasi \\ Dokter Internship Puskesmas Panekan, Magetan, Jawa Timur \\ Dokter Internship RSAU dr. Efram Harsana, Magetan, Jawa Timur
}

Korespondensi: rosasanyasi@gmail.com

\begin{abstract}
ABSTRAK
Pendahuluan: Leptospirosis merupakan penyakit zoonosis yang disebabkan oleh bakteri Leptospira sp. Lepstospirosis banyak dijumpai di negara tropis dan negara berkembang, termasuk Indonesia. Timbulnya atau meningkatnya kejadian kesakitan dan/ atau kematian yang bermakna secara epidemiologi pada suatu daerah dalam kurun waktu tertentu dan merupakan keadaan yang dapat menjurus pada terjadinya wabah disebut sebagai kejadian luar biasa (KLB). Selama ini belum pernah terdapat kasus leptospirosis yang dijumpai di Magetan, Jawa Timur.

Tujuan: Laporan kasus ini bertujuan untuk menjabarkan kronologi KLB leptospirosis di Magetan, Jawa Timur.

Hasil dan Pembahasan: Pasien perempuan berusia 40 tahun datang ke Puskesmas Panekan, Magetan, Jawa Timur dengan keluhan demam sejak 6 hari sebelumnya disertai dengan mual, muntah, nyeri di perut sebelah kanan, nyeri pada kedua betis, sesak nafas, dan sklera berubah menjadi berwarna kuning. Pasien menjalani rawat inap di Puskesmas. Dari hasil pemeriksaan darah dan urin, diperoleh leukositosis, peningkatan SGOT, SGPT, alkalin phosphatase, BUN, kreatinin, serta terdapat proteinuria dan hematuria. Pada hari kedua rawat inap, pasien mengeluh pandangan menjadi kabur, demam semakin meningkat, buang air kecil semakin sedikit, disertai rasa nyeri, dan berwarna kuning kemerahan. Pasien dirujuk ke rumah sakit umum daerah, tetapi pasien meninggal pada hari kesembilan dari onset penyakit dan rapid diagnostic test (RDT) belum sempat dilakukan. Kasus ini termasuk dalam kasus probable leptospirosis. Meskipun belum sempat dilakukan pemeriksaan RDT, Dinas Kesehatan Magetan sepakat menyatakan kasus ini sebagai kasus KLB oleh karena hingga menimbulkan kematian.

Kesimpulan: Telah dilaporkan kasus probable leptospirosis pada bulan Februari 2017 yang dinyatakan sebagai KLB di Magetan, Jawa Timur oleh karena menyebabkan kematian pada pasien.
\end{abstract}

Kata Kunci: laporan kasus, leptospirosis, kejadian luar biasa, Lepstospira sp 


\title{
CASE REPORT OF ANOMALOUS EVENT OF LEPTOSPIROSIS IN MAGETAN, EAST JAVA
}

\author{
Rosa De Lima Renita Sanyasi \\ Internship Doctor at Panekan Public Health Care, Magetan, East Java \\ Internship Doctor at dr. Efram Harsana Air Force Hospital, Magetan, East Java
}

Correspondence: rosasanyasi@gmail.com

\begin{abstract}
Introduction: Leptopirosis is a zoonosis caused by Leptospira $s p$. Lepstospirosis is easy to find in tropical and developing countries, including Indonesia. Anomalous event defined as an incidence or increasing of incidence of morbidity and/or mortality significantly in an area within a certain period of time. There has never been a leptospirosis case in Magetan, East Java.

Objective: This case report aimed to explain the chronology of anomalous event of leptospirosis in Magetan, East Java.

Results and Discussion: A female patient, 40 years old, came to Panekan Public Health Care (PHC) with fever as the main problem. Patient was also complaining other symptoms including: nausea, vomitus, right quadrant abdominal pain, calf pain, dyspnea, and icteric sclera. The patient suggested to stay at Panekan PHC for an observation. On the second day in Panekan PHC, patient was complaining of blurry vision, increasing fever, pain during urinate with few urinary output. Patient transffered to regional hospital. The patient deteriorated and pass away on the ninth day from the onset of disease. Rapid diagnostic test (RDT) was not yet performed. Eventhough this case classified as a probable of leptospirosis, Department of Health in Magetan considered this case as an anomalous event of leptospirosis.

Conclusion: This case is classified as an anomalous event of leptospirosis in Magetan, East Java because it was causing death on patient with probable leptospirosis.
\end{abstract}

Keywords: case report, leptospirosis, anomalous event, Lepstospira sp 


\section{PENDAHULUAN}

Leptospirosis merupakan penyakit zoonosis yang disebabkan oleh bakteri Leptospira sp. yang masih termasuk dalam famili Leptospiraceae dan ordo Spirochatales. ${ }^{1}$ Leptospirosis ditularkan dari binatang ke manusia baik secara langsung maupun tidak langsung. Berbagai faktor yang meningkatkan risiko seseorang terinfeksi bakteri Leptospira antara lain: kepadatan penduduk yang tinggi, pengelolaan sampah yang kurang baik, kondisi iklim (cuaca hangat, hujan, dan banjir), sanitasi buruk, pekerjaan tertentu (penambang, petani, dan peternak), serta aktivitas rekreasi (memancing dan berenang). ${ }^{2}$

Setiap tahun kejadian leptospirosis diperkirakan mencapai 1.03 juta kasus di seluruh dunia (95\% CI: 0.43-1.75). ${ }^{3}$ Leptospirosis paling banyak dijumpai di negara tropis dan di negara berkembang. ${ }^{4}$ Asia Tenggara merupakan salah satu daerah endemis leptospirosis. ${ }^{1}$ Prevalensi dan insidensi leptospirosis di Indonesia selalu berubah setiap tahun. Pada tahun 2008 terdapat 131 penduduk Semarang dengan leptospirosis positif. 5 Pada tahun 2012 dilaporkan terdapat 239 kasus leptospirosis dengan 29 kasus kematian di Indonesia (case fatality rate 12.13\%). 6 Pada tahun 2013, 2014, dan 2015 jumlah kasus leptospirosis di Indonesia secara berturut-turut adalah 640, 545, dan 336 kasus, sedangkan jumlah di Jawa Timur secara berturut-turut adalah 244, 61, 3 kasus. ${ }^{7}$ Terdapat penurunan jumlah kasus leptospirosis yang signifikan pada daerah Jawa Timur dari tahun 2013 hingga 2015. Angka kematian akibat leptospirosis di Indonesia berkisar antara $2.5 \%$ sampai $16.4 \% .8$

Kejadian Luar Biasa (KLB) adalah timbulnya atau meningkatnya kejadian kesakitan dan/ atau kematian yang bermakna secara epidemiologi pada suatu daerah dalam kurun waktu tertentu dan merupakan keadaan yang dapat menjurus pada terjadinya wabah. ${ }^{9}$ Berdasarkan hasil wawancara pada tanggal 23 Oktober 2017 dengan petugas di bidang Pengendalian Penyakit (P2) di Dinas Kesehatan Magetan dan Kepala Puskesmas Panekan, selama ini belum pernah terdapat kasus leptospirosis di Magetan, baik kasus suspek, probable, maupun konfirmasi. Pada bulan Februari 2017 terdapat 2 kasus leptospirosis yang terjadi di desa Banjarejo dan desa Turi, Magetan, Jawa Timur. Kedua pasien tersebut merupakan dua kasus leptospirosis pertama di Magetan. Satu dari dua pasien tersebut meninggal dunia sehingga Dinas Kesehatan Magetan menetapkan kejadian ini sebagai KLB.

Laporan kasus ini menjabarkan KLB leptospirosis pada bulan Februari 2017, di Desa Turi, Kecamatan Panekan, Kabupaten Magetan, Jawa Timur. Tujuan dari penulisan laporan kasus ini adalah untuk menjabarkan kronologi KLB leptospirosis di Magetan, Jawa Timur.

\section{LAPORAN KASUS}

Pada tanggal 8 Februari 2017, seorang pasien perempuan berinisial RK berusia 40 tahun datang ke Puskesmas Panekan, Magetan, Jawa Timur dengan keluhan demam sejak 6 hari sebelumnya. Demam dirasakan meningkat pada sore atau malam hari dan terasa membaik pada pagi hari. Demam disertai dengan rasa nyeri di seluruh badan, mual, dan muntah.

Pasien mengeluh nyeri di perut sebelah kanan yang semakin memberat dan nyeri pada kedua betis. Sejak dua hari sebelum datang ke Puskesmas pasien merasa sesak 
nafas. Satu hari sebelum datang ke Puskesmas sklera pasien berubah menjadi berwarna kuning (Gambar 1).

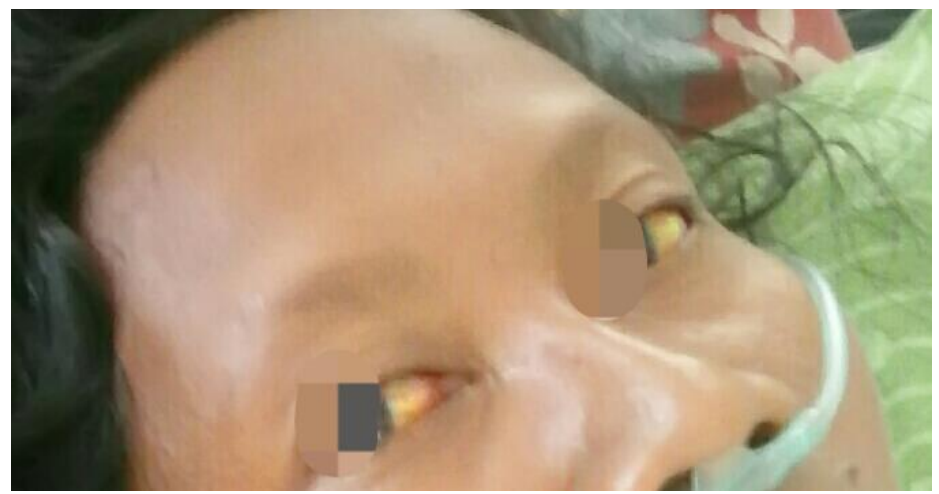

Gambar 1. Sklera Ikterik Nyonya RK

Riwayat penyakit lain sebelumnya seperti penyakit hepatitis disangkal oleh pasien. Riwayat berpergian jauh, khususnya ke Indonesia bagian timur, disangkal oleh pasien. Sejauh pengetahuan pasien, tidak ada tetangga di sekitarnya yang mengalami keluhan serupa. Selama mengalami keluhan tersebut pasien hanya meminum obat penurun demam yang dibeli dari toko obat. Pasien merupakan ibu rumah tangga dan sehari-hari banyak beraktivitas di rumah.

Pasien tampak lemas dengan kesadaran compos mentis. Tekanan darah (TD) pasien adalah 130/80 $\mathrm{mmHg}$, dengan frekuensi nadi $(\mathrm{N}) 100$ kali per menit, frekuensi respirasi (R) 22 kali per menit, dan suhu (T) $36^{\circ} \mathrm{C}$.
Pemeriksaan fisik pada Nyonya RK didapatkan sklera ikterik pada kedua mata, nyeri tekan pada regio hipokondrium dekstra, ikterik pada kedua palmar dan plantar pedis. Berdasarkan semua keluhan tersebut, dokter Puskemas menyarankan pasien untuk menjalani rawat inap di Puskesmas. Hasil pemeriksaan laboratorium nyonya RK pada hari pertama rawat inap tampak pada Tabel 1. Dari hasil pemeriksaan darah, diperoleh peningkatan leukosit, SGOT, dan SGPT. Pemeriksaan HbsAg menunjukkan hasil negatif. Pemeriksaan urin pasien menunjukkan adanya proteinuria dan hematuria.

Tabel 1. Pemeriksaan Laboratorium Hari Pertama Rawat Inap

\begin{tabular}{lclc}
\hline Pemeriksaan Darah & Hasil & Pemeriksaan Urin & Hasil \\
\hline Hemoglobin (mg/dL) & 13.2 & $\mathrm{pH}$ & 5.0 \\
Leukosit (/mmk) & 26610 & Berat Jenis & 1020 \\
Trombosit (/mmk) & 175000 & Warna & Kuning Kemerahan \\
Hematokrit (\%) & 36.3 & Bau & Khas \\
SGOT (U/L) & 61.99 & Tingkat Kejernihan & Keruh \\
SGPT (U/L) & 53.62 & Protein & +2 \\
HbsAg & Negatif & Nitrit & +1 \\
Widal & $1 / 80$ & Leukosit $(/ 1 \mathrm{pb})$ & $4-5$ \\
& & Eritrosit $(/ \mathrm{pb})$ & $6-8$ \\
& & Epitel $(/ 1 \mathrm{pb})$ & $2-14$ \\
& & Test Kehamilan & Negatif \\
\hline
\end{tabular}

SGOT: Serum Glutamic Oxaloacetic Transaminase,

SGPT: Serum Glumatat-Pyruvate Transaminase 
Pada hari kedua rawat inap, pasien mengeluh pandangan menjadi kabur dan demam semakin meningkat. Buang air kecil semakin sedikit, disertai rasa nyeri, dan berwarna kuning kemerahan. TD pasien pada hari kedua rawat inap adalah 130/80 mmHg, N 120 kali per menit, R 24 kali per menit, dan $\mathrm{T}$ $39.3^{\circ} \mathrm{C}$. Hasil pemeriksaan fisik didapatkan sklera ikterik, conjunctival suffusion pada kedua mata, nyeri tekan pada regio hipokondrium kanan dan regio suprapubik, serta ikterik pada kedua palmar dan plantar pedis.

Selama rawat inap di Puskemas pasien mendapatkan terapi infus $\mathrm{NaCl} 20$ tetes per menit (tpm), injeksi cefotaxime 1 gram dua kali per hari, injeksi ranitidin $150 \mathrm{mg}$ dua kali per hari, injeksi metamizole 1 ampul satu kali per hari, hepatoprotektor 1 tablet per hari, antipiretik satu tablet tiga kali per hari, dan antasida satu tablet tiga kali per hari. Pasien juga diberikan oksigenasi dengan nasal kanul 3 liter per menit (lpm) dan dilakukan pemasangan kateter pada hari kedua rawat inap.

Hasil pemeriksaan laboratorium pada hari kedua rawat inap tampak pada tabel 2. Kadar leukosit, SGOT, dan SGPT sedikit menurun jika dibandingkan dengan hari pertama rawat inap. Kadar alkalin fosfatase, BUN, dan kreatinin pasien meningkat.

Tabel 2. Pemeriksaan Laboratorium Hari Kedua Rawat Inap

\begin{tabular}{lc}
\hline \multicolumn{1}{c}{ Pemeriksaan Darah } & Hasil \\
\hline Hemoglobin (mg/dL) & 12.6 \\
Leukosit (/mmk) & 2570 \\
Trombosit (/mmk) & 180000 \\
Hematokrit (\%) & 34.4 \\
SGOT (U/L) & 46 \\
SGPT (U/L) & 21 \\
HbsAg & Negatif \\
Widal & $1 / 80$ \\
Albumin & 2.8 \\
Alkalin Fosfatase & 87 \\
BUN (mg/dL) & 111 \\
Kreatinin (mg/dL) & 5.8 \\
\hline
\end{tabular}

SGOT: Serum Glutamic Oxaloacetic Transaminase,

SGPT: Serum Glumatat-Pyruvate Transaminase,

BUN: Blood Urea Nitrogen

\begin{abstract}
Pasien dirujuk ke rumah sakit umum daerah (RSUD) setempat karena kondisi yang semakin menurun. TD pasien saat dirujuk adalah 130/80 mmHg, N 120 kali per menit, R 30 kali per menit, dan $\mathrm{T}$ $39^{\circ} \mathrm{C}$. Setelah menjalani rawat inap di RSUD selama satu hari, pasien meninggal dunia yaitu pada hari kesembilan dari onset penyakit.

Standar baku yang disepakati oleh dinas kesehatan Magetan dalam menegakkan diagnosis leptospirosis
\end{abstract}

adalah dengan pemeriksaan rapid diagnostic test (RDT) untuk mendeteksi IgM anti Leptospira dalam darah pasien. Puskesmas Panekan tempat pasien menjalani rawat inap pertama kali tidak memiliki alat RDT, sehingga selama rawat inap di Puskesmas pemeriksaan tersebut tidak dapat dilakukan. Pada hari kesembilan dari onset penyakit, Nyonya RK baru dapat dirujuk ke RSUD tetapi perburukan cepat terjadi hingga 
pasien meninggal. Hal tersebut menyebabkan RDT belum dapat dilakukan.

Terdapat 3 kriteria dalam mendiagnosis leptopirosis, yaitu kasus suspek, probable, dan konfirmasi. Kriteria kasus suspek meliputi: demam akut dengan atau tanpa sakit kepala, disertai nyeri otot, lemah (malaise), conjungtival suffusion, dan ada riwayat terpapar dengan lingkungan yang terkontaminasi atau aktifitas yang merupakan faktor risiko leptospirosis dalam kurun waktu 2 minggu. Kriteria kasus probable adalah jika terdapat dua gejala klinis di antara tanda-tanda berikut: a) nyeri betis; b) sklera ikterik; c) manifestasi pendarahan; d) sesak nafas; e) oliguria atau anuria; f) aritmia jantung; g) batuk dengan atau tanpa hemoptisis; dan h) ruam kulit. Selain itu, memiliki gambaran laboratorium: a) Trombositopenia < 100.000 $\mathrm{sel} / \mathrm{mm}$; b) Leukositosis dengan neutropilia > 80\%; c) Kenaikan jumlah bilirubin total > $2 \mathrm{gr} \%$ atau peningkatan SGPT, amilase, lipase, dan creatine phosphokinase (CPK); dan d) penggunaan RDT. Kasus konfirmasi ditegakkan apabila kasus probable disertai salah satu dari gejala berikut: a) isolasi bakteri Leptospira dari spesimen klinik; b) hasil Polymerase Chain Reaction (PCR) positif; dan c) Sero konversi microscopic agglutination test (MAT) dari negatif menjadi positif. 10,11

Kasus Nyonya RK termasuk dalam kasus probable leptospirosis karena gejala yang khas, pemeriksan fisik, dan hasil pemeriksaan laboratorium darah yang mendukung. Meskipun belum sempat dilakukan RDT, Dinas Kesehatan Magetan sepakat menyatakan kasus ini sebagai kasus KLB oleh karena kasus ini hingga menimbulkan kematian.

Beberapa petugas dari Puskesmas Panekan dan Dinas
Kesehatan Magetan melakukan kunjungan pada rumah Nyonya RK untuk meninjau sanitasi pada rumah pasien tersebut. Lantai rumah pasien masih berupa lantai tanah dan sebagian besar kurang mendapat pencahayaan. Selama melakukan kunjungan, di dalam rumah pasien dijumpai banyak tikus. Tampak pula banyak tumpukan barang di dalam rumah pasien.

\section{PEMBAHASAN}

Perjalanan penyakit leptospirosis dapat dibedakan menjadi 2 fase, yaitu fase septikemik atau fase leptospiremik dan fase imun. Pada fase septikemik penderita akan mengalami gejala mirip flu, meliputi demam, nyeri otot pada betis, paha, pinggang terutama saat ditekan, 12 mual dan muntah.13 Gejala-gejala tersebut dialami oleh pasien pada kasus ini. Conjunctival suffusion merupakan dilatasi pembuluh darah konjungtiva tanpa eksudat purulen. Adanya conjunctival suffusion menjadi tanda patognomonik leptospirosis. ${ }^{14}$ Gejala ini tampak pada Nyonya RK. Leptospirosis dapat dibagi menjadi dua, yaitu leptospirosis anikterik dan leptospirosis ikterik yang disebut juga penyakit Weill. Pada kasus ini, leptospirosis yang muncul adalah penyakit Weill. Penyakit Weill adalah jenis leptospirosis yang paling sering menyebabkan kematian. ${ }^{15}$

Pemeriksaan laboratorium untuk mendiagnosis leptospirosis dibagi menjadi dua, yaitu pemeriksaan untuk mendeteksi antibodi anti-leptospira dan untuk mendeteksi bakteri leptospira secara langsung, antigen, maupun asam nukleat lepstospira. ${ }^{16}$ Pemeriksaanpemeriksaan tersebut antara lain: (i) microscopic agglutination test (MAT) untuk mendeteksi antibodi terhadap Leptospira secara serologis, (ii) polymerase chain reaction (PCR) untuk mendeteksi gen spesifik 
Leptospira, (iii) kultur darah atau dari cairan tubuh lain, ${ }^{13}$ (iv) IgM ELISA untuk menemukan antibodi IgM spesifik leptospira, 17 dan (v) RDT. Standar baku dalam menegakkan diagnosis leptospirosis adalah dengan menemukan bakteri Leptospira secara langsung menggunakan mikroskop lapangan gelap atau dengan kultur. ${ }^{18}$

Pemeriksaan leptopirosis yang biasa digunakan di suatu daerah endemis adalah RDT. Pemeriksaan RDT adalah pemeriksaan yang digunakan untuk mendeteksi antibodi IgM pada darah. Pemeriksaan ini hanya untuk skrining awal dan memiliki angka sensitivitas tidak lebih dari 80\% sehingga tetap perlu diikuti dengan pemeriksaan lain. ${ }^{19}$ Pemeriksaan RDT yang sering dijumpai adalah Lepto dipstick, Lepto lateral flow, dan Lepto Dridot. 5 Tingkat kepositifan dari tes skrining tergantung pada jumlah antibodi spesifik dalam serum spesimen yang berkaitan dengan stadium penyakit. ${ }^{20}$ Peralatan laboratorium tersebut untuk menegakkan diagnosis leptospirosis juga masih sangat terbatas. ${ }^{21}$ Sama halnya dengan kasus ini dimana Puskesmas setempat tidak memiliki alat RDT dan hanya RSUD setempat yang memilikinya, sehingga penegakkan diagnosis tidak dapat segera dilakukan.

Pemeriksaan penunjang lainnya meliputi pemeriksaan kimia darah dan urinalisis. Pemeriksaan kimia darah yang bermakna pada kasus leptospirosis diantaranya adalah peningkatan fungsi hepar dan alkalin fosfatase.22 Peningkatan kedua parameter tersebut tampak pada Nyonya RK. Pada leptospirosis berat bisa terjadi leukositosis disertai trombositopenia. ${ }^{22}$ Nyonya RK hanya mengalami leukositosis tetapi tidak trombositopenia. Gangguan fungsi renal pada pasien leptospirosis ditunjukkan dengan peningkatan kadar kreatinin. ${ }^{22}$ Nyonya RK mengalami gangguan fungsi renal yang tampak jelas pada hari kedua rawat inap, yang ditandai dengan oliguria dan kadar kreatinin mencapai $5.8 \mathrm{mg} / \mathrm{dL}$. Urinalisis pada penderita leptospirosis menunjukkan adanya proteinuria, piuria, dan hematuria mikroskopis. ${ }^{22}$ Pada Nyonya RK hanya dijumpai proteinuria dan hematuria. Ditemukan leukosit pada urin Nyonya RK sebanyak 4-5 lpd, tetapi jumlah tersebut belum cukup untuk dikategorikan sebagai piuria.

Leptospirosis dapat ditularkan oleh berbagai hewan diantaranya adalah tikus dan hewan domestik seperti sapi, babi, anjing, domba, kambing, kuda, dan kerbau. ${ }^{11}$ Keberadaan reservoir khususnya tikus sangat penting diketahui dalam upaya pengendalian dan pemutusan rantai penularan. ${ }^{23}$ Kondisi rumah Nyonya RK memang sangat berpotensi menjadi sumber infeksi leptospirosis oleh karena banyaknya tikus yang dijumpai di dalam rumah dan banyaknya barang yang bertumpuk yang berpotensi menjadi sarang tikus. Edukasi pada keluarga Nyonya RK dan pada masyarakat sekitar mengenai kebersihan lingkungan sangat penting dilakukan untuk mencegah wabah leptospirosis.

\section{KESIMPULAN}

Telah dilaporkan kasus probable leptospirosis pada bulan Februari 2017. Pasien tersebut meninggal dunia pada hari kesembilan dari onset penyakit. Kasus tersebut disepakati oleh Dinas Kesehatan Magetan sebagai sebuah KLB oleh karena hingga menimbulkan kematian pada pasien.

\section{DAFTAR PUSTAKA}

1. Ahmed SA, Sandai DA, Musa S, et al. Rapid diagnosis of 
leptospirosis by multiplec pcr. Malays J Med Sci. 2012;19(3):916.

2. Benacer D, Thong KL, Verasahib $\mathrm{KB}$, et al. Human leptospirosis in malaysia: reviewing the challenges after 8 decades (19252012). Asia Pas J of Pub Health. 2016;doi:10.1177/10105395166 40350.

3. Costa F, Hagan JE, Calcagno J, et al. Global morbidity and mortality of leptospirosis: a systematic review. PloS Negl Trop Dis. 2015;9(9):e0003898:doi:10.1371 /journal. pntd.0003898.

4. Marinho M. Leptospirosis: epidemiologic factors, pathophysiological, and immunopathogenic. China: In Tech. 2012; p.43.

5. Hariastuti NI. Diagnosis leptospirosis dan karakterisasi leptospira secara molekuler. Balaba. 2011;7(2):59-61.

6. Kementerian Kesehatan Republik Indonesia. Profil pengendalian penyakit dan penyehatan lingkungan tahun 2012. Jakarta: Kementerian Kesehatan. 2012.

7. Kementerian Kesehatan Republik Indonesia. Profil kesehatan indonesia tahun 2015. Jakarta: Kementerian Kesehatan RI. 2016;p.198.

8. Priyanto A, Hadisaputro S, Santoso L, et al. Faktor-faktor risiko yang berpengaruh terhadap kejadian leptospirosis (studi kasus di Kabupaten Demak). Jurnal Epidemiologi Universitas Diponegoro. 2008: 2-5.

9. Menteri Kesehatan Republik Indonesia. Peraturan Menteri Kesehatan Republik Indonesia nomor 1501/MENKES/PER/X

/2010 tentang pedoman penyelenggaraan sistem kewaspadaan dini kejadian luar biasa (KLB). Jakarta: Kementerian Kesehatan Republik Indonesia. 2010; p.4.

10. Kementerian Kesehatan Republik Indonesia. Leptospirosis: Kenali dan Waspadai. Available at: www.depkes.go.id [Accessed at: December 15th 2017].

11. Rampengan NH. Leptospirosis. Jurnal Biomedik. 2016;8(3):14350.

12. Jaksa S. Leptospirosis. Jurnal Kedokteran dan Kesehatan 2010;6(2):119-128.

13. Chappuis F, Alirol E, d'Acremont $\mathrm{V}$, et al. Rapid Diagnostic Test for Non-Malarial Febrile Illness in the Tropics. Clin Microbiol and Infection. 2013;DOI 10.1111/ 1469-0691.

14. Haake DA. Leptospirosis in Humans. Curr Top Microbiol Immunol. 2015;387: 65-97. doi:10.1007/978-3-662-450598_5.

15. Amin LZ. Leptospirosis CDK-243. 2016;43(8) 576-80.

16. Gamage CD, Tasmashiro $\mathrm{H}$, Ohnishi M, Koizumi N. Epidemiology, Surveillance and Laboratory Diagnosis of Leptospirosis in the WHO SouthEast Asia Region. China: In Tech, 2012;p.219.

17. Dohe VB, Pol SS, Karmarkar AP, et al. Two test strategy for the diagnosis of leptospirosis. Bombay Hospital Journal. 2009;51(1).

18. Setiawan IM. Pemeriksaan Laboratorium untuk Mendiagnosis Penyakit Leptospirosis. 
Media Litbang Kesehatan 2008;XVIII(1):44-52.

19. Goris MGA, Leeflang MMG, Loden $\mathrm{M}$, et al. Prospective Evaluation of Three Rapid Diagnostic Tests for Diagnosis of Human Leptospirosis PLoS Negl Trop Dis. 7(7): e2290. doi:10.1371/ journal.pntd. 0002290.

20. Yunianto B, Ramadhani T, Ikawati B, et al. Studi reservoir dan distribusi kasus leptospirosis di kabupaten gresik tahun 2010. Jurnal Ekologi Kesehatan. 2012;11(1):40-51.

21. Sakundarno M, Bertolatti D, Maycock B, Spickett J, Dhaliwal
S. Risk factors for leptospirosis infection in humans and implications for public health intervention in Indonesia and the Asia-Pacific region. Asia Pac $\mathrm{J}$ Public Health. 2014;26:15-32.

22. Budihal SV, Perwez. Leptospirosis diagnosis: competancy of various laboratory tests. Journal of Clinical and Diagnostic Research. 2014;8(1):199-202.

23. Ramadhani T, Yunianto B. Reservoir dan kasus leptospirosis di wilayah kejadian luar biasa. jurnal kesehatan masyarakat. 2012;7(4):162-8. 